\title{
Post COVID-19 Syndrome in Patients with Asymptomatic/Mild Form
}

\author{
Anna Malkova ${ }^{1, *} \oplus$, Igor Kudryavtsev ${ }^{2}$, Anna Starshinova ${ }^{3}$, Dmitry Kudlay ${ }^{4,5} \odot$, Yulia Zinchenko ${ }^{6} \oplus$, \\ Anzhela Glushkova ${ }^{7}$, Piotr Yablonskiy ${ }^{1,6}$ and Yehuda Shoenfeld ${ }^{1,8,9}$
}

check for updates

Citation: Malkova, A.; Kudryavtsev, I.; Starshinova, A.; Kudlay, D.; Zinchenko, Y.; Glushkova, A.; Yablonskiy, P.; Shoenfeld, Y. Post COVID-19 Syndrome in Patients with Asymptomatic/Mild Form. Pathogens 2021, 10, 1408. https://doi.org/ $10.3390 /$ pathogens 10111408

Academic Editors: Luis

Martinez-Sobrido and Marta

L. DeDiego

Received: 7 October 2021

Accepted: 28 October 2021

Published: 30 October 2021

Publisher's Note: MDPI stays neutral with regard to jurisdictional claims in published maps and institutional affiliations.

Copyright: (c) 2021 by the authors. Licensee MDPI, Basel, Switzerland. This article is an open access article distributed under the terms and conditions of the Creative Commons Attribution (CC BY) license (https:/ / creativecommons.org/licenses/by/ $4.0 /)$.
1 Medical Department, St-Petersburg State University, 199034 Saint-Petersburg, Russia; piotr_yablonskii@mail.ru (P.Y.); yehuda.shoenfeld@sheba.health.gov.il (Y.S.)

2 Department of Immunology, Institution of Experimental Medicine, 197376 Saint-Petersburg, Russia; igorek1981@yandex.ru

3 Almazov National Medical Research Centre, 197341 Saint-Petersburg, Russia; starshinova_aa@almazovcentre.ru

4 Medical Department, I.M. Sechenov First Moscow State Medical University, 119435 Moscow, Russia; D624254@gmail.com

5 NRC Institute of Immunology FMBA of Russia, 115478 Moscow, Russia

6 St. Petersburg Research Institute of Phthisiopulmonology, 199034 Saint-Petersburg, Russia; ulia-zinchenko@yandex.ru

7 V.M. Bekhterev National Research Medical Center for Psychiatry and Neurology, 192019 Saint-Petersburg, Russia; angela_glushkova@yahoo.com

8 Ariel University, Kiryat HaMada 3, Ariel 40700, Israel

9 Zabludowicz Center for Autoimmune Diseases, Sheba Medical Center, Tel-Hashomer 5265601, Israel

* Correspondence: anya.malkova.95@mail.ru

Abstract: Post COVID-19 Syndrome (PCS) is a complex of various symptoms developing a month or more after the acute phase of the disease. The cases of PCS development among patients with asymptomatic/mild forms are frequently reported; however, the pathogenesis of PCS in this group of patients is still not completely clear. The publications about COVID-19 which were published in online databases from December 2019 to September 2021 are analyzed in this review. According to the analysis, PCS develops on average in 30-60\% of patients, mainly among women. Fatigue, shortness of breath, cough, and anosmia were reported as the most common symptoms. The possible association between the described PCS symptoms and brain damage was revealed. We assume the possibility of an alternative course of COVID-19, which develops in genetically predisposed individuals with a stronger immune response, in which it predominantly affects the cells of the nervous system, possibly with the presence of an autoimmune component, which might have similarity with chronic fatigue syndrome or autoimmune disautonomia. Thus, the gender (female) and the presence of anosmia during an asymptomatic or mild course of the disease can be predictive factors for the development of PCS, which can be caused by autoimmune damage to neurons, glia, and cerebral vessels.

Keywords: COVID-19; asymptomatic; mild; Post COVID-19 Syndrome; autoimmune; anosmia; fatigue; Myalgic Encephalomyelitis/Chronic Fatigue Syndrome; autoimmune dysautonomia

\section{Introduction}

The new coronavirus infection was first reported in December 2019, and it has claimed the lives of people around the world. Currently, there concern is growing about the consequences after suffering COVID-19 caused by SARS-CoV-2 virus (severe acute respiratory syndrome-related coronavirus 2).

SARS-CoV-2 enters into cells that only express ACE2 (angiotensin-converting enzyme 2) but not into cells without ACE2 or cells expressing other coronavirus receptors such as aminopeptidase $\mathrm{N}$ and dipeptidyl peptidase 4 (DPP4), suggesting that ACE2 is a unique cellular receptor for SARS-CoV-2 [1]. Extensive organ damage occurs because ACE2 is 
highly expressed not only for cells of the lung and vascular endothelium, but also on myocardial cells, renal proximal tubule and bladder urothelial cells, and cells of the testis, intestine, and liver [2]. Moreover, the presence of a long-term damaging viral agent, hyper inflammatory reactions, and a decrease in the expression of ACE 2 downregulate recovery processes [3,4].

The complication of the disease, including mild course, can be manifested by the development of the so-called Post COVID-19 Syndrome (PCS), which does not have clear criteria for its prevention, diagnosis, and management tactics. At the moment, there is no single approach to its definition and classification. Various authors classify complications depending on the genesis, time of its onset, and the form of acute infection (Table 1), for example, the consequences of complications during the illness, complications of treatment, or reemerging symptoms (Table 1).

Table 1. Proposed PCS classifications.

\begin{tabular}{|c|c|c|}
\hline Amenta EM et al. [5] & Ceravolo MG et al. [6] & $\begin{array}{c}\text { Centers for Disease Control and } \\
\text { Prevention [7] }\end{array}$ \\
\hline $\begin{array}{l}\text { residual symptoms that persist after } \\
\text { recovery from acute } \\
\text { SARS-CoV-2 infection }\end{array}$ & $\begin{array}{l}\text { symptoms persisting from the acute } \\
\text { phase and their treatment }\end{array}$ & $\begin{array}{l}\text { persistent COVID series of symptoms last } \\
\text { for weeks or months }\end{array}$ \\
\hline $\begin{array}{l}\text { symptoms due to single or multiple } \\
\text { organ dysfunction that persists after } \\
\text { initial recovery }\end{array}$ & symptoms associated with a new disease & $\begin{array}{l}\text { symptoms resulting from damage to } \\
\text { multiple organs, such as the heart, lung, } \\
\text { kidneys, skin, and nervous system }\end{array}$ \\
\hline $\begin{array}{l}\text { novel symptoms or syndromes that arise } \\
\text { after mild or asymptomatic infection }\end{array}$ & $\begin{array}{l}\text { late-onset symptoms resulting from } \\
\text { COVID-19 arising at the end of the } \\
\text { acute phase } \\
\text { impact on a previous pathology } \\
\text { or disability }\end{array}$ & $\begin{array}{c}\text { consequences of COVID-19 treatment or } \\
\text { prolonged hospitalisation }\end{array}$ \\
\hline
\end{tabular}

The most common symptoms were fatigue (35-72\%), dyspnea (29-65\%), sleep disturbance $(57 \%)$, cough $(43 \%)$, asthenia $(40 \%)$, memory problems $(34 \%)$, anosmia $(21-23 \%)$, and arthralgia (20-22\%) [8]. According to various databases, $20 \%$ of patients had at least one symptom of PCS during the month or more after the disease, and $10 \%$ of patients during 3 or more months after $[9,10]$. According to the British National Institute for Health Research, PCS developed in a significant proportion of non-hospitalized patients; at least one symptom was observed after a month among $20-30 \%$ of patients, and after 3 months among $10 \%$ [11].

Given the widespread infection and the high level of PCS development even in asymptomatic and mild forms, it is necessary to reveal the pathogenic features of the syndrome development in these patients to identify high-risk groups.

\section{Methods}

The review analyzes publications about COVID-19 in online databases "Medline" / PubMed" and "Scopus" from December 2019 to September 2021. The first selection of articles was based on the keywords COVID-19, asymptomatic, mild, pathogenesis, immune system, Post COVID-19 Syndrome, and autoimmune, anosmia. The inclusion criteria were asymptomatic or mild forms of COVID-19 diagnosed with PCR test, the development of PCS symptoms a minimum of 1 month after, and the description of the developed PCS symptoms. Due to the small number of published papers and the variability of samples studied, we considered it impossible to carry out a systematic review of high quality following the recent PRISMA guidelines.

\section{Results}

At this moment there are a few studies of patients with asymptomatic or mild forms of COVID-19 (Table 2). 
Table 2. The data of the studies on PCS among patients with asymptomatic or mild forms of COVID-19.

\begin{tabular}{|c|c|c|c|c|}
\hline Authors & Sample & Period of Observation & Symptoms (\%) & PCS $(\%)$ \\
\hline \multirow[t]{2}{*}{$\begin{array}{l}\text { Augustin M et al. } \\
{[12]}\end{array}$} & $\begin{array}{l}958 \text { SARS-CoV-2-convalescent patients, } \\
\text { the majority initially presented with }\end{array}$ & 4 months & $\begin{array}{l}\text { anosmia (12.4), ageusia } \\
(11.1) \text {, fatigue (9.7), and } \\
\text { shortness of breath (8.6) }\end{array}$ & 27.8 \\
\hline & absent to mild symptoms & 7 months & & 34.8 \\
\hline $\begin{array}{l}\text { Tenforde MW } \\
\text { et al. [13] }\end{array}$ & $\begin{array}{c}292 \text { young patients (mean age: } \\
42.5 \text { years) with mild COVID-19 } 16 \text { days } \\
\text { after diagnosis }\end{array}$ & 2-3 weeks & $\begin{array}{l}\text { cough, fatigue, } \\
\text { and dyspnea }\end{array}$ & 35.0 \\
\hline $\begin{array}{c}\text { Carvalho- } \\
\text { Schneider C et al. } \\
\text { [14] }\end{array}$ & 150 patients with mild COVID-19 & 2 months & $\begin{array}{c}\text { asthenia (40.0), } \\
\text { dyspnoea (30.0) } \\
\text { anosmia/ageusia (23.0) }\end{array}$ & 66.7 \\
\hline $\begin{array}{l}\text { Yong Huang et al. } \\
{[15]}\end{array}$ & $\begin{array}{c}1407 \text { records } \\
\text { No hospitalized }\end{array}$ & 60 days & $\begin{array}{l}\text { shortness of breath, } \\
\text { chest pain, cough, or } \\
\text { abdominal pain }\end{array}$ & 27.0 \\
\hline $\begin{array}{c}\text { Tabacof L et al. } \\
{[16]}\end{array}$ & 84 less severe acute infection with PCS & 151 (54 to 255 ) days & $\begin{array}{c}\text { fatigue }(92.0 \%), \text { loss of } \\
\text { concentra- } \\
\text { tion/memory }(74.0), \\
\text { weakness }(68.0), \\
\text { headache }(65.0), \text { and } \\
\text { dizziness }(64.0) \\
\text { fatigue (13.6) and loss }\end{array}$ & $\begin{array}{l}\text { All } 84 \text { were } \\
\text { with PCS }\end{array}$ \\
\hline $\begin{array}{c}\text { Logue JK et al. } \\
{[17]}\end{array}$ & $\begin{array}{c}177 \\
11(6.2 \%) \text { were asymptomatic, } 150 \\
(84.7 \%) \text { were outpatients with mild } \\
\text { illness, and } 16(9.0 \%) \text { had moderate or } \\
\text { severe disease requiring hospitalization }\end{array}$ & 9 months & $\begin{array}{l}\text { of sense of smell or } \\
\text { taste }(13.6) . \\
23 \text { patients }(13.0 \%) \\
\text { reported other } \\
\text { symptoms, including } \\
\text { brain fog }(2.3)\end{array}$ & 32.7 \\
\hline $\begin{array}{l}\text { Melanie L. Bell } \\
\text { et al. [18] }\end{array}$ & 303 no hospitalized & $\begin{array}{c}\text { 30-59 days } \\
\text { post-diagnosis }\end{array}$ & $\begin{array}{l}\text { fatigue (37.5), shortness } \\
\text { of breath (37.5), brain } \\
\text { fog (30.8), and } \\
\text { stress/anxiety (30.8) }\end{array}$ & 68.7 \\
\hline & & $\geq 60$ days & & 73.0 \\
\hline Havervall S et al. & $323(94 \%)$ seropositive & $\begin{array}{l}2 \text { months } \\
8 \text { months }\end{array}$ & $\begin{array}{l}\text { anosmia, fatigue, } \\
\text { ageusia, and dyspnea }\end{array}$ & $\begin{array}{l}26.0 \\
15.0\end{array}$ \\
\hline & and $1072(84 \%)$ seronegative & 2 months & & 9.0 \\
\hline & participants & 8 months & $\begin{array}{l}\text { fatigue (16.0), } \\
\text { concentration or } \\
\text { memory difficulties }\end{array}$ & 3.0 \\
\hline $\begin{array}{l}\text { Bliddal S et al. } \\
\text { [20] }\end{array}$ & $\begin{array}{c}445 \text { Danish non-hospitalized } \\
\text { Completely asymptomatic COVID-19 } \\
\text { was reported by } 34 \%\end{array}$ & $\geq 4$ weeks & $\begin{array}{l}\text { (13.0), reduced sense of } \\
\text { smell (10.0), and } \\
\text { shortness of } \\
\text { breath (10.0) } \\
\text { fatigue (16.0) and }\end{array}$ & 36.0 \\
\hline & & $\geq 12$ weeks & $\begin{array}{l}\text { concentration } \\
\text { difficulties (13.0) }\end{array}$ & 40.0 \\
\hline $\begin{array}{l}\text { Fernández-de- } \\
\text { Las-Peñas C et al. } \\
\text { [21] }\end{array}$ & 9011 non-hospitalized patients & $\begin{array}{l}\geq \text { one post-COVID-19 } \\
\text { symptom at } 30,60, \text { or } \\
\geq 90 \text { days after onset }\end{array}$ & $\begin{array}{l}\text { Fatigue and dyspnea } \\
\quad 35.0-60.0 \\
\text { cough }(20.0-25.0), \\
\text { anosmia }(10.0-20.0) \\
\text { ageusia }(15.0-20.0) \text {, or } \\
\text { joint pain }(15.0-20.0)\end{array}$ & 45.9 \\
\hline $\begin{array}{l}\text { Andrews PJ et al. } \\
\text { [22] }\end{array}$ & $\begin{array}{l}\text { Mild to moderate Health Care Workers } \\
\qquad 114\end{array}$ & 52 days & $\begin{array}{c}\text { olfactory } 73.1 \\
\text { taste alteration } 69.2\end{array}$ & \\
\hline
\end{tabular}

Analysis of the described data allows us to do several conclusions:

- PCS developed among 30-60\% of patients with asymptomatic or mild forms of COVID19 on average. 
- The most common symptoms were fatigue, shortness of breath, cough, anosmia, and ageusia. Headaches, brain fog, and other symptoms of central nervous system damage were also reported.

- Most common PCS occurs among women (on average 60\%).

\section{Discussion}

\subsection{Pathogenesis of the Described Complications}

The cause of multiorgan damage due to coronavirus infection may be explained by the direct effect on cells by viruses as well as immune-mediated and vascular complications [23]. However, there is no consensus on the pathogenesis of the development of the particular symptoms currently.

\subsubsection{Fatigue}

According to Nauen et al.'s hypothesis, fatigue may be caused by the dysfunction of the capillaries of the brain [24]. Perhaps this could explain the development of postural orthostatic tachycardia syndrome (POTS) after SARS-CoV-2 infection, which is defined by heart rate increase $>30$ beats per minute after head-up tilting test [25], palpitations, and tachycardia without obvious cardiac abnormalities [26]. This autonomic dysfunction, including orthostatic hypotension, vasovagal syncope, and POTS, was described in patients with mild forms of COVID-19 [27]. The autoimmune origin of these diseases is considered $[28,29]$ with autoantibodies to $\alpha$-/ $\beta$-adrenoceptors and muscarinic receptors detected [30].

According to Townsend et al. [31], patients with fatigue that developed an average of 166 days after infection did not have the autonomic dysfunction criteria from Ewing's battery parameters. The researchers found an association between fatigue and anxiety that was not diagnosed in any participant before COVID-19. However, the researchers did not perform autoantibodies detection; therefore, it is impossible to exclude autoimmune etiology of developed fatigue.

Association between fatigue and anxiety suggests the presence of Myalgic Encephalomyelitis/Chronic Fatigue Syndrome (ME/CFS) [32]. ME/CFS is a chronic disease with autoimmune origin [33] characterized by unexplained fatigue after exercise, and symptoms are associated with cognitive, immunological, endocrinological, and autonomic dysfunction, which are currently attributed to brain damage [34]. The main target of ME/CFS is considered to be the brain stress center, a cluster of neurons in the paraventricular nucleus of the hypothalamus [35,36], which might be damaged by autoantibodies to 5hydroxytryptamine, gangliosides, and phospholipids [33]. It is assumed that infection with SARS-CoV-2 in certain individuals may be a trigger for the development of ME/CFS, being a serious physiological stressor. Thus, in a study of a small group of patients, according to the diagnostic criteria, CFS was detected 6 months after infection [37]. It is important to note that ME/CFS is more common among women [38], and symptoms of fatigue and anxiety are common after coronavirus infection.

\subsubsection{Shortness of Breath, Cough}

According to the Liam Townsend study, the majority of patients with mild forms had a normal chest X-ray with a decrease in desaturation during the six-minute walking test (6MWT) 75 days after diagnosis [39]; therefore, fibrosis is not the cause of shortness breath in mild forms.

According to the hypothesis of Townsend et al. [40], delayed lung damage after SARS-CoV-2 infection may be caused by an autoimmune response to ACE2, which can be explained by the forced presentation of the ACE2 protein in complex with CoV spike in Fc receptor-positive antigen-presenting cells. One of the explanations of the development of autoimmune complications might be also the molecular similarity of SARS-CoV-2 S-protein with surfactant proteins, which was shown in the Kanduc et al. study [41]. According to Cappello F et al., hypoxia during the infection might induce expression of 
antistress proteins, including heat shock proteins (Hsp), that have a high level of structural conservation and share various similar antigens within and across species. It might be the cause of immunological crossreactivity between Hsp/chaperones and virus proteins that leads to autoimmune reactivity [42]. Generated antibodies might damage endothelium cells with the development of thrombosis, disseminated intravascular coagulation, and multi-organ failure $[43,44]$.

The possible cross-reactions leading to the activation of autoimmune processes in the lungs damaging pneumocytes and endotheliocytes can be considered. These findings might allow to assume the presence of the delayed interstitial pneumonia and fibrosis after a longer period; therefore, during the clinical studies, these inflammatory autoimmune changes are not so well expressed for X-ray imaging.

\subsubsection{Anosmia}

The cause of anosmia is considered to be the dysfunction of lymphatic drainage from the periventricular organs and the direct viral invasion into the extracellular spaces of the olfactory epithelium $[45,46]$. Significant amounts of SARS-CoV S protein and RNA have been found in the cells of the olfactory mucosa [47]. According to Gordon et al., one of the mechanisms of penetration of the virus into the cells of the olfactory epithelium may be interaction with opioid receptors sigma-1 and sigma-2 [48]. It is worth noting that anosmia is also more common among female patients [49].

\subsubsection{Headaches, Brain, and Other CNS Symptoms}

The development of headaches and other CNS symptoms may be the result of virus damage to both brain cells and blood vessels, which was shown on autopsy materials (inflammatory foci, changes in the parenchyma and blood vessels) [50,51]. It is assumed that prolonged inflammation, accompanied by the release of TNF- $\alpha$, can cause cognitivebehavioral changes [52,53].

The evidence of the presence of viral RNA in the brain and cerebrospinal fluid (CSF) has been published; however, according to the researchers, it does not indicate a true infection with SARS-CoV-2 [54]. On the other hand, ACE2 expression was found in neuronal and glial cells of the central nervous system [55], in the olfactory mucosa [56]. Meinhardt et al. suggest that the virus can enter through the olfactory tract into certain neuroanatomical areas, including the main control center of the respiratory and cardiovascular systems in the medulla oblongata [47], which might explain the development of shortness of breath in patients.

\subsection{The Hypothesis}

According to the analysis of the literature, it can be assumed that the most common symptoms of PCS are characterized by the presence of nerve cell damage and have similarities with CFS and disautonomia, which are autoimmune diseases. According to the study by Wallukat et al. [57], patients with the symptoms mostly of neurological origin (including post-COVID-19 fatigue, attention deficit, tremor and others) were positive for antibodies to chronotropic GPCR-fAABs targeting the $\beta 2$-adrenoceptor, the $\alpha 1$-adrenoceptor, the angiotensin II AT1-receptor, and the nociception-like opioid receptor and negative to chronotropic GPCR-fAABs targeting the muscarinic M2-receptor, the MAS-receptor, and the ETA-receptor, which are also found in POTS and dysautonomia [58]. In patients who have had a mild and severe coronavirus infection, there are significant changes in the composition of circulating immune cells, which persist for a long time (at least 3 to 9 months after the acute phase of the disease) and are similar to autoimmune diseases.

Firstly, this is an increase in the proportion of pro-inflammatory T-helper 17 (Th17) cells circulating in the blood for a long time after the disease and a decrease in anti-inflammatory T-regulatory cells (Tregs), accompanied by a change in the Th17/Treg balance [59-61], which is specifically for a wide range of autoimmune diseases [62]. 
Secondly, an imbalance between T-follicular helper (Tfh) cell subpopulations and regulatory (Tfr) was observed [63], which is also noted in autoimmune manifestations associated with the formation of autoantibodies $[64,65]$.

Thirdly, in the peripheral blood of COVID-19 patients, an increased number of short-living, highly differentiated $\mathrm{CD} 8^{+} \mathrm{T}$-lymphocytes remaining for a long time was found [58-61,64], which indicates the ongoing processes of differentiation and circulation of these cells from the lymphoid tissue. These cells, apparently, are not associated more with the elimination of SARS-CoV-2 and its antigens, but may be another sign of the development of an autoimmune reaction [66]. An increase in the proportion of mature effector cells with the CD45RA ${ }^{+} \mathrm{CCR} 7^{-}$phenotype in the peripheral blood of convalescent patients was noted, and in the case of $\mathrm{CD} 8^{+}$cytotoxic $\mathrm{T}$ cells, this was also associated with an increase in the proportion of mature perforin- and granzyme-expressing lymphocytes, which are capable of producing TNF $\alpha$ and IFN $\gamma$ [59]. Moreover, the presence of pulmonary complications was closely associated with an increase in the circulation of the proportion of short-living effector $\mathrm{CD} 27-\mathrm{CD} 62 \mathrm{~L}-\mathrm{CD} 8^{+} \mathrm{T}$ cells, as well as mature $\mathrm{T}$ cells capable of producing perforin, granzyme $\mathrm{B}$, and IFN $\gamma$ [60]. It was also noted that 1.5-2.5 months after the acute phase of COVID-19, a high level of granzyme ${ }^{+} \mathrm{CD} 8^{+} \mathrm{T}$ cells remained in the peripheral blood of the recovered patients [67].

An important feature in the development of PCS after the asymptomatic/mild form is the predominance of female patients $[14,20,68]$. It is known that the female gender is a protective factor against the development of severe infections [69]. This is facilitated by several physiological characteristics, in particular:

- immunomodulatory functions of estrogen and immunosuppressive functions of testosterone [70,71];

- $\quad$ higher expression and poly-morphisms of ACE-2 and TMPRSS2 genes associated with a genetic predisposition to COVID-19 in men [72-74];

- $\quad$ higher number of activated and terminally differentiated T cell populations (CD38 and HLA-DR-positive activated T cells) among women [75];

- $\quad$ higher average serum concentrations of SARS-CoV-2 IgG antibodies at an early stage of infection among women [76,77].

With a more pronounced immune response, women are more predisposed to developing autoimmune diseases [78], in particular ME/CFS, fibromyalgia, etc.

We assume that among patients with a stronger immune response, the virus, when it enters the upper respiratory tract, damages the cells of the olfactory mucosa predominantly, which develops anosmia, and then is transferred to the brain by lymphatic drainage or axonal transport. After a little while, an inflammatory reaction with an autoimmune component develops, which might explain the development of CNS damage symptoms (fatigue, headaches, etc.) after a month or more. The virus can also damage the respiratory and cardiovascular centers, which might explain shortness of breath.

According to the hypothesis of Wostyn, the development of anosmia might be a predictive factor of the development of PCS, in particular fatigue [79], which might confirm the concept of the proposed pathogenesis (Figure 1).

We assume that there is an alternative form of the course of coronavirus infection, mainly affecting the cells of the nervous system and developing in genetically predisposed individuals (in particular among women). One of the genetic predisposing factors, besides the expression of ACE 2 and the protein associated with it, can be genotypes HLA-A*02:01 and HLA-A*03:01, associated with a low probability of developing a severe form of COVID19 [80], and HLA-DRB1*04: 01 associated with asymptomatic infection [81] (Figure 2). 


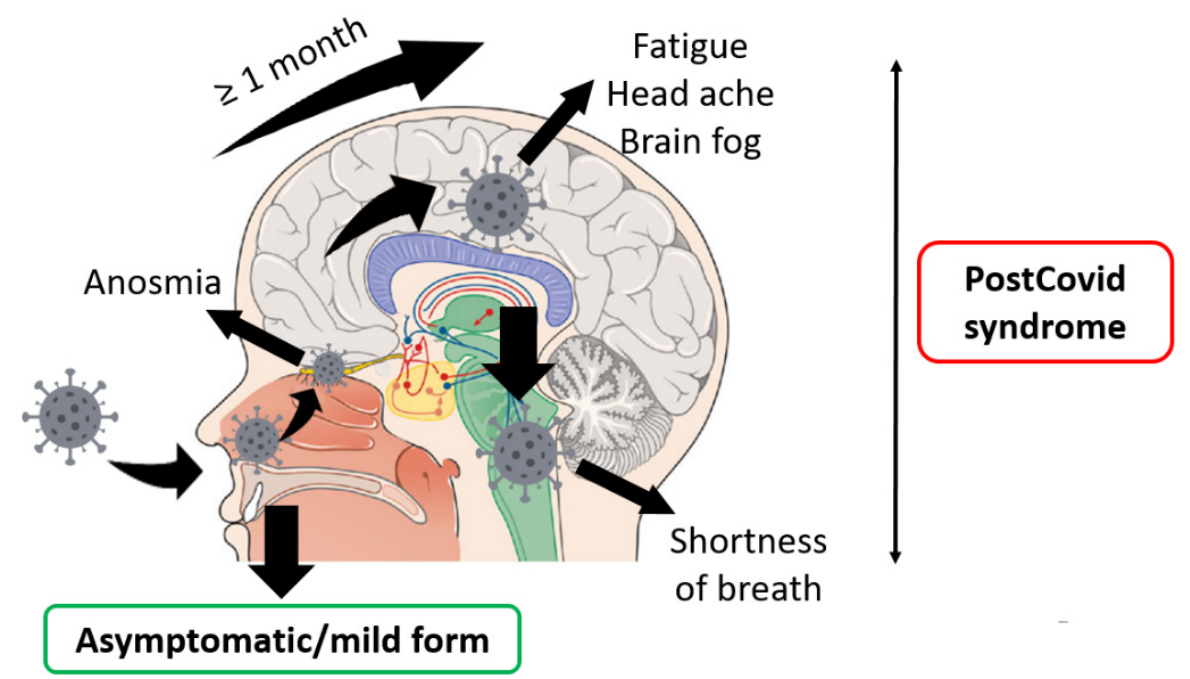

Figure 1. Schematic explanation of the PCS pathogenesis affecting CNS.

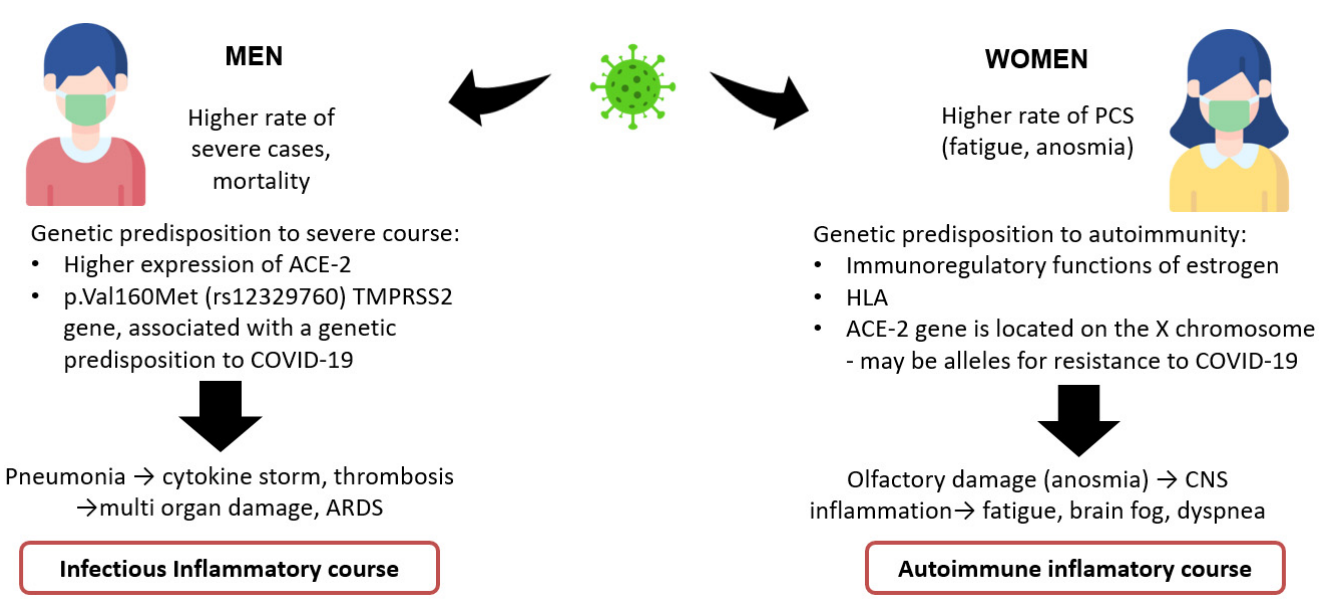

Figure 2. Hypothesis on different forms of COVID-19.

It is worth considering other complications of coronavirus infection in patients with mild forms of the disease, mediated by thrombotic or endocrine complications. Joseph et al. [82] described four clinical cases of thromboebolism in patients with a mild form. However, in all cases, complications occurred earlier than 2 weeks after the first symptoms, which does not fit into the PCS and indicates a second wave of organ damage by the virus in a more severe form [83]. A similar conclusion could be done from the clinical case of a long-segment arterial cerebral vessel thrombosis after mild form of COVID-19 14 days after the first symptoms, described by Sartoretti et al. [84].

\section{Conclusions}

According to the analysis of original articles on PCS among asymptomatic/mild COVID-19 patients, PCS develops on average in 30-60\% of patients, mainly among women, with fatigue, shortness of breath, cough, and anosmia being the most common symptoms. The possible association between the described PCS symptoms and brain damage during coronavirus infection suggests an alternative form of the course of the disease that develops in genetically predisposed individuals with a stronger immune response (in particular women), in which it predominantly affects the cells of the nervous system with the presence of an autoimmune component, which has similarities with Myalgic Encephalomyelitis/Chronic Fatigue Syndrome or autoimmune disautonomia. In summary, the female gender and the presence of anosmia during an asymptomatic or mild form of the disease could be predictive factors of the development of PCS, which might be caused by autoimmune damage to neurons, glia, and cerebral vessels. 
Author Contributions: A.M. and I.K. analysis of the materials, wrote the manuscript; A.S. analysis of the materials, wrote the manuscript, coordinator of the project; D.K., Y.Z., and A.G. wrote the manuscript; P.Y. coordinator of the project, wrote the manuscript; Y.S. coordinator of the project. All authors have read and agreed to the published version of the manuscript.

Funding: Government funding was obtained from Almazov National Medical Research Centre of the Ministry of Health of Russian Federation and St. Petersburg Scientific Research Institute of Phthisiopulmonology of the Ministry of Health of Russian Federation.

Institutional Review Board Statement: Not applicable.

Informed Consent Statement: Not applicable.

Data Availability Statement: All data generated or analyzed during this study are included in this published article.

Acknowledgments: This work is supported by the grant of the Government of the Russian Federation for the state support of scientific research carried out under the supervision of leading scientists, agreement 14.W03.31.0009.

Conflicts of Interest: The authors declare that they have no competing interests.

\section{References}

1. Ni, W.; Yang, X.; Yang, D.; Bao, J.; Li, R.; Xiao, Y.; Hou, C.; Wang, H.; Liu, J.; Yang, D.; et al. Role of angiotensin-converting enzyme 2 (ACE2) in COVID-19. Crit. Care 2020, 24, 422. [CrossRef]

2. Zhang, H.; Li, H.B.; Lyu, J.R.; Lei, X.M.; Li, W.; Wu, G.; Lyu, J.; Dai, Z.M. Specific ACE2 expression in small intestinal enterocytes may cause gastrointestinal symptoms and injury after 2019-nCoV infection. Int. J. Infect. Dis. 2020, 96, 19-24. [CrossRef]

3. Ojo, A.S.; Balogun, S.A.; Williams, O.T.; Ojo, O.S. Pulmonary Fibrosis in COVID-19 Survivors: Predictive Factors and Risk Reduction Strategies. Pulm. Med. 2020, 2020, 6175964. [CrossRef]

4. Gudima, G.O.; Khaitov, R.M.; Kudlay, D.A.; Khaitov, M.R. Molecular immunological aspects of diagnostics, prevention and treatment of coronavirus infection. Immunologiya 2021, 42, 198-210. [CrossRef]

5. Amenta, E.M.; Spallone, A.; Rodriguez-Barradas, M.C.; El Sahly, H.M.; Atmar, R.L.; Kulkarni, P.A. Postacute COVID-19: An overview and approach to classification. In Open Forum Infectious Diseases; Oxford University Press: Oxford, UK, 2020 ; Volume 7.

6. Ceravolo, M.G.; Arienti, C.; De Sire, A.; Andrenelli, E.; Negrini, F.; Lazzarini, S.G.; Patrini, M.; Negrini, S. Rehabilitation and COVID-19: The Cochrane Rehabilitation 2020 rapid living systematic review. Eur. J. Phys. Rehabil. Med. 2020, 56, 642-651. [CrossRef]

7. Post-COVID Conditions I CDC. Available online: https://www.cdc.gov/coronavirus/2019-ncov/long-term-effects/index.html (accessed on 26 October 2021).

8. Carod-Artal, F.J. Post-COVID-19 syndrome: Epidemiology, diagnostic criteria and pathogenic mechanisms involved. Rev. Neurol. 2021, 72, 384-396. [CrossRef] [PubMed]

9. Ladds, E.; Rushforth, A.; Wieringa, S.; Taylor, S.; Rayner, C.; Husain, L.; Greenhalgh, T. Persistent symptoms after COVID-19: Qualitative study of 114 "long Covid" patients and draft quality principles for services. BMC Health Serv. Res. 2020, $20,1-13$. [CrossRef] [PubMed]

10. Coronavirus (COVID-19) Infection Survey, UK Statistical Bulletins-Office for National Statistics. Available online: https:/ / www.ons.gov.uk/peoplepopulationandcommunity/healthandsocialcare/conditionsanddiseases/bulletins/coronaviruscovid1 9infectionsurveypilot/previousReleases (accessed on 26 October 2021).

11. Living with COVID-19—Second Review. 2021. Available online: https://evidence.nihr.ac.uk/themedreview/living-with-covid1 9-second-review/ (accessed on 26 October 2021).

12. Augustin, M.; Schommers, P.; Stecher, M.; Dewald, F.; Gieselmann, L.; Gruell, H.; Horn, C.; Vanshylla, K.; Di Cristanziano, V.; Osebold, L.; et al. Post-COVID syndrome in non-hospitalised patients with COVID-19: A longitudinal prospective cohort study. Lancet Reg. Health Eur. 2021, 6, 100122. [CrossRef] [PubMed]

13. Tenforde, M.W.; Kim, S.S.; Lindsell, C.J.; Rose, E.B.; Shapiro, N.I.; Files, D.C.; Gibbs, K.W.; Erickson, H.L.; Steingrub, J.S.; Smithline, H.A.; et al. Symptom Duration and Risk Factors for Delayed Return to Usual Health Among Outpatients with COVID19 in a Multistate Health Care Systems Network-United States, March-June 2020. Morb. Mortal. Wkly. Rep. 2020, 69, 993-998. [CrossRef]

14. Carvalho-Schneider, C.; Laurent, E.; Lemaignen, A.; Beaufils, E.; Bourbao-Tournois, C.; Laribi, S.; Flament, T.; Ferreira-Maldent, N.; Bruyère, F.; Stefic, K.; et al. Follow-up of adults with noncritical COVID-19 two months after symptom onset. Clin. Microbiol. Infect. 2021, 27, 258-263. [CrossRef]

15. Huang, Y.; Pinto, M.D.; Borelli, J.L.; Mehrabadi, M.A.; Abrihim, H.; Dutt, N.; Lambert, N.; Nurmi, E.L.; Chakraborty, R.; Rahmani, A.M.; et al. COVID Symptoms, Symptom Clusters, and Predictors for Becoming a Long-Hauler: Looking for Clarity in the Haze of the Pandemic. medRxiv 2021, medRxiv:21252086. 
16. Tabacof, L.; Tosto-Mancuso, J.; Wood, J.; Cortes, M.; Kontorovich, A.; McCarthy, D.; Rizk, D.; Nasr, L.; Breyman, E.; Mohammadi, N.; et al. Post-acute COVID-19 syndrome negatively impacts health and wellbeing despite less severe acute infection. medRxiv 2020. medRxiv:20226126.

17. Logue, J.K.; Franko, N.M.; McCulloch, D.J.; McDonald, D.; Magedson, A.; Wolf, C.R.; Chu, H.Y. Sequelae in Adults at 6 Months after COVID-19 Infection. JAMA Netw. Open 2021, 4, e210830. [CrossRef]

18. Bell, M.L.; Catalfamo, C.J.; Farland, L.V.; Ernst, K.C.; Jacobs, E.T.; Klimentidis, Y.C.; Jehn, M.; Pogreba-Brown, K. Post-acute sequelae of COVID-19 in a non-hospitalized cohort: Results from the Arizona CoVHORT. PLoS ONE 2021, 16, e0254347. [CrossRef] [PubMed]

19. Havervall, S.; Rosell, A.; Phillipson, M.; Mangsbo, S.M.; Nilsson, P.; Hober, S.; Thålin, C. Symptoms and Functional Impairment Assessed 8 Months after Mild COVID-19 among Health Care Workers. JAMA—J. Am. Med Assoc. 2021, 325, 2015-2016. [CrossRef] [PubMed]

20. Bliddal, S.; Banasik, K.; Pedersen, O.B.; Nissen, J.; Cantwell, L.; Schwinn, M.; Tulstrup, M.; Westergaard, D.; Ullum, H.; Brunak, S.; et al. Acute and persistent symptoms in non-hospitalized PCR-confirmed COVID-19 patients. Sci. Rep. 2021, 11, 13153. [CrossRef]

21. Fernández-De-Las-Peñas, C.; Palacios-Ceña, D.; Gómez-Mayordomo, V.; Florencio, L.L.; Cuadrado, M.L.; Plaza-Manzano, G.; Navarro-Santana, M. Prevalence of post-COVID-19 symptoms in hospitalized and non-hospitalized COVID-19 survivors: A systematic review and meta-analysis. Eur. J. Intern. Med. 2021, 92, 55-70. [CrossRef]

22. Andrews, P.J.; Pendolino, A.L.; Ottaviano, G.; Scarpa, B.; Grant, J.; Gaudioso, P.; Bordin, A.; Marchese-Ragona, R.; Leoni, D.; Cattelan, A.; et al. Olfactory and taste dysfunction among mild-to-moderate symptomatic COVID-19 positive health care workers: An international survey. Laryngoscope Investig. Otolaryngol. 2020, 5, 1019-1028. [CrossRef]

23. Nalbandian, A.; Sehgal, K.; Gupta, A.; Madhavan, M.V.; McGroder, C.; Stevens, J.S.; Cook, J.R.; Nordvig, A.S.; Shalev, D.; Sehrawat, T.S.; et al. Post-acute COVID-19 syndrome. Nat. Med. 2021, 27, 601-615. [CrossRef]

24. Nauen, D.W.; Hooper, J.E.; Stewart, C.M.; Solomon, I.H. Assessing Brain Capillaries in Coronavirus Disease 2019. JAMA Neurol. 2021, 78, 760-762. [CrossRef]

25. Miglis, M.G.; Prieto, T.; Shaik, R.; Muppidi, S.; Sinn, D.I.; Jaradeh, S. A case report of postural tachycardia syndrome after COVID-19. Clin. Auton. Research. Nat. Publ. Group 2020, 30, 449-451. [CrossRef] [PubMed]

26. Lau, S.T.; Yu, W.C.; Mok, N.S.; Tsui, P.T.; Tong, W.L.; Stella, W.C. Tachycardia amongst subjects recovering from severe acute respiratory syndrome (SARS). Int. J. Cardiol. 2005, 100, 167-169. [CrossRef] [PubMed]

27. Dani, M.; Dirksen, A.; Taraborrelli, P.; Torocastro, M.; Panagopoulos, D.; Sutton, R.; Lim, P.B. Autonomic dysfunction in 'long COVID': Rationale, physiology and management strategies. Clinical Medicine. J. R. Coll. Physicians Lond. 2021, 21, E63.

28. Halpert, G.; Watad, A.; Tsur, A.M.; Dotan, A.; Quiros-Lim, H.E.; Heidecke, H.; Gilburd, B.; Haik, J.; Levy, Y.; Blank, M.; et al. Autoimmune dysautonomia in women with silicone breast implants. J. Autoimmun. 2021, 120, 102631. [CrossRef] [PubMed]

29. Schofield, J.R.; Blitshteyn, S.; Shoenfeld, Y.; Hughes, G.R.V. Postural tachycardia syndrome (POTS) and other autonomic disorders in antiphospholipid (Hughes) syndrome (APS). Lupus 2014, 23, 697-702. [CrossRef]

30. Yu, X.; Stavrakis, S.; Hill, M.A.; Huang, S.; Reim, S.; Li, H.; Khan, M.; Hamlett, S.; Cunningham, M.W.; Kem, D.C. Autoantibody activation of beta-adrenergic and muscarinic receptors contributes to an "autoimmune" orthostatic hypotension. J. Am. Soc. Hypertens. 2012, 6, 40-47. [CrossRef]

31. Townsend, L.; Moloney, D.; Finucane, C.; McCarthy, K.; Bergin, C.; Bannan, C.; Kenny, R.-A. Fatigue following COVID-19 infection is not associated with autonomic dysfunction. PLoS ONE 2021, 16, e0247280. [CrossRef]

32. Mackay, A. A Paradigm for Post-COVID-19 Fatigue Syndrome Analogous to ME/CFS. Front. Neurol. 2021, 12, 1334. [CrossRef]

33. Ryabkova, V.A.; Churilov, L.P.; Shoenfeld, Y. Neuroimmunology: What role for autoimmunity, neuroinflammation, and small fiber neuropathy in fibromyalgia, chronic fatigue syndrome, and adverse events after human papillomavirus vaccination? Int. J. Mol. Sci. 2019, 20, 5164. [CrossRef]

34. Cortes Rivera, M.; Mastronardi, C.; Silva-Aldana, C.T.; Arcos-Burgos, M.; Lidbury, B.A. Myalgic encephalomyelitis/chronic fatigue syndrome: A comprehensive review. Diagnostics. Diagn. 2019, 9, 91. [CrossRef]

35. Mackay, A. A neuro-inflammatory model can explain the onset, symptoms and flare-ups of myalgic encephalomyelitis/chronic fatigue syndrome. J. Prim. Health Care 2019, 11, 300-307. [CrossRef]

36. Mackay, A.; Tate, W.P. A compromised paraventricular nucleus within a dysfunctional hypothalamus: A novel neuroinflammatory paradigm for ME/CFS. Int. J. Immunopathol. Pharmacol. 2018, 32, 2058738418812342. [CrossRef]

37. Petracek, L.S.; Suskauer, S.J.; Vickers, R.F.; Patel, N.R.; Violand, R.L.; Swope, R.L.; Rowe, P.C. Adolescent and Young Adult ME/CFS After Confirmed or Probable COVID-19. Front. Med. 2021, 8, 668944. [CrossRef]

38. Lim, E.J.; Ahn, Y.C.; Jang, E.S.; Lee, S.W.; Lee, S.H.; Son, C.G. Systematic review and meta-analysis of the prevalence of chronic fatigue syndrome/myalgic encephalomyelitis (CFS/ME). J. Transl. Medicine. BioMed Cent. 2020, 18, 1-15. [CrossRef] [PubMed]

39. Townsend, L.; Dowds, J.; O’Brien, K.; Sheill, G.; Dyer, A.H.; O’Kelly, B.; Hynes, J.P.; Mooney, A.; Dunne, J.; Ni Cheallaigh, C.; et al. Persistent poor health after COVID-19 is not associated with respiratory complications or initial disease severity. Ann. Am. Thorac. Soc. 2021, 18, 997-1003. [CrossRef]

40. Townsend, A. Autoimmunity to ACE2 as a possible cause of tissue inflammation in COVID-19. Med. Hypotheses 2020, 144, 110043. [CrossRef] [PubMed]

41. Kanduc, D.; Shoenfeld, Y. On the molecular determinants of the SARS-CoV-2 attack. Clin. Immunol. 2020, 215, 108426. [CrossRef] 
42. Cappello, F.; Marino Gammazza, A.; Dieli, F.; Conway de Macario, E.; Macario, A.J. Does sars-cov-2 trigger stress-induced autoimmunity by molecular mimicry? A hypothesis. J. Clin. Med. 2020, 9, 2038. [CrossRef] [PubMed]

43. Gammazza, A.M.; Légaré, S.; Bosco, G.L.; Fucarino, A.; Angileri, F.; de Macario, E.C.; Macario, A.J.; Cappello, F. Human molecular chaperones share with SARS-CoV-2 antigenic epitopes potentially capable of eliciting autoimmunity against endothelial cells: Possible role of molecular mimicry in COVID-19. Cell Stress Chaperones 2020, 25, 737-741. [CrossRef]

44. Cappello, F. Is COVID-19 a proteiform disease inducing also molecular mimicry phenomena?. Cell Stress and Chaperones. Cell Stress Chaperones 2020, 25, 381-382. [CrossRef] [PubMed]

45. Perrin, R.; Riste, L.; Hann, M.; Walther, A.; Mukherjee, A.; Heald, A. Into the looking glass: Post-viral syndrome post COVID-19. Med. Hypotheses 2020, 144, 110055. [CrossRef] [PubMed]

46. Morbini, P.; Benazzo, M.; Verga, L.; Pagella, F.G.; Mojoli, F.; Bruno, R.; Marena, C. Ultrastructural evidence of direct viral damage to the olfactory complex in patients testing positive for SARS-COV-2. JAMA Otolaryngol.—Head Neck Surg. 2020, 146, 972-973. [CrossRef] [PubMed]

47. Meinhardt, J.; Radke, J.; Dittmayer, C.; Franz, J.; Thomas, C.; Mothes, R.; Laue, M.; Schneider, J.; Brünink, S.; Greuel, S.; et al. Olfactory transmucosal SARS-CoV-2 invasion as a port of central nervous system entry in individuals with COVID-19. Nat. Neurosci. 2021, 24, 168-175. [CrossRef]

48. Gordon, D.E.; Jang, G.M.; Bouhaddou, M.; Xu, J.; Obernier, K.; White, K.M.; O’Meara, M.J.; Rezelj, V.V.; Guo, J.Z.; Swaney, D.L.; et al. A SARS-CoV-2 protein interaction map reveals targets for drug repurposing. Nature 2020, 583, 459-468. [CrossRef]

49. Lee, Y.; Min, P.; Lee, S.; Kim, S.-W. Prevalence and duration of acute loss of smell or taste in COVID-19 patients. J. Korean Med. Sci. 2020, 35, e174. [CrossRef]

50. Romero-Sánchez, C.M.; Díaz-Maroto, I.; Fernández-Díaz, E.; Sánchez-Larsen, Á.; Layos-Romero, A.; García-García, J.; González, E.; Redondo-Peñas, I.; Perona-Moratalla, A.B.; Del Valle-Pérez, J.A.; et al. Neurologic manifestations in hospitalized patients with COVID-19: The ALBACOVID registry. Neurology 2020, 95, e1060-e1070. [CrossRef]

51. Reichard, R.R.; Kashani, K.B.; Boire, N.A.; Constantopoulos, E.; Guo, Y.; Lucchinetti, C.F. Neuropathology of COVID-19: A spectrum of vascular and acute disseminated encephalomyelitis (ADEM)-like pathology. Acta Neuropathol. 2020, 140, 1-6. [CrossRef]

52. Bortolato, B.; Carvalho, A.F.; Soczynska, J.K.; Perini, G.I.; McIntyre, R.S. The Involvement of TNF- $\alpha$ in Cognitive Dysfunction Associated with Major Depressive Disorder: An Opportunity for Domain Specific Treatments. Curr. Neuropharmacol. 2015, 13, 558-576. [CrossRef] [PubMed]

53. Aiello, A.; Farzaneh, F.; Candore, G.; Caruso, C.; Davinelli, S.; Gambino, C.M.; Ligotti, M.E.; Zareian, N.; Accardi, G. Immunosenescence and its hallmarks: How to oppose aging strategically? A review of potential options for therapeutic intervention. Front. Immunol. 2019, 10, 2247. [CrossRef]

54. Moriguchi, T.; Harii, N.; Goto, J.; Harada, D.; Sugawara, H.; Takamino, J.; Ueno, M.; Sakata, H.; Kondo, K.; Myose, N.; et al. A first case of meningitis/encephalitis associated with SARS-Coronavirus-2. Int. J. Infect. Dis. 2020, 94, 55-58. [CrossRef]

55. Khan, S.; Gomes, J. Neuropathogenesis of SARS-CoV-2 infection. Elife 2020, 9, e59136. [CrossRef] [PubMed]

56. Brann, D.H.; Tsukahara, T.; Weinreb, C.; Lipovsek, M.; Van den Berge, K.; Gong, B.; Chance, R.; Macaulay, I.C.; Chou, H.J.; Fletcher, R.B.; et al. Non-neuronal expression of SARS-CoV-2 entry genes in the olfactory system suggests mechanisms underlying COVID-19-associated anosmia. Sci. Adv. 2020, 6, eabc5801. [CrossRef] [PubMed]

57. Wallukat, G.; Hohberger, B.; Wenzel, K.; Fürst, J.; Schulze-Rothe, S.; Wallukat, A.; Hönicke, A.-S.; Müller, J. Functional autoantibodies against G-protein coupled receptors in patients with persistent Long-COVID-19 symptoms. J. Transl. Autoimmun. 2021, 4, 100100. [CrossRef]

58. Kharraziha, I.; Axelsson, J.; Ricci, F.; Di Martino, G.; Persson, M.; Sutton, R.; Fedorowski, A.; Hamrefors, V. Serum activity against g protein-coupled receptors and severity of orthostatic symptoms in postural orthostatic tachycardia syndrome. J. Am. Heart Assoc. 2020, 9, e015989. [CrossRef] [PubMed]

59. Shuwa, H.A.; Shaw, T.N.; Knight, S.B.; Wemyss, K.; McClure, F.A.; Pearmain, L.; Prise, I.; Jagger, C.; Morgan, D.J.; Khan, S.; et al. Alterations in $\mathrm{T}$ and $\mathrm{B}$ cell function persist in convalescent COVID-19 patients. Med [Letter] 2021, 2, 720-735.e4. [CrossRef]

60. Wu, J.; Tang, L.; Ma, Y.; Li, Y.; Zhang, D.; Li, Q.; Mei, H.; Hu, Y. Immunological Profiling of COVID-19 Patients with Pulmonary Sequelae. mBio 2021, 12, e0159921. [CrossRef]

61. Orologas-Stavrou, N.; Politou, M.; Rousakis, P.; Kostopoulos, I.V.; Ntanasis-Stathopoulos, I.; Jahaj, E.; Tsiligkeridou, E.; Gavriatopoulou, M.; Kastritis, E.; Kotanidou, A.; et al. Peripheral blood immune profiling of convalescent plasma donors reveals alterations in specific immune subpopulations even at 2 months post sars-cov-2 infection. Viruses 2021, 13, 26. [CrossRef]

62. Knochelmann, H.M.; Dwyer, C.J.; Bailey, S.R.; Amaya, S.M.; Elston, D.M.; Mazza-McCrann, J.M.; Paulos, C.M. When worlds collide: Th17 and Treg cells in cancer and autoimmunity. Cell. Mol. Immunol. 2018, 15, 458-469. [CrossRef] [PubMed]

63. Gong, F.; Dai, Y.; Zheng, T.; Cheng, L.; Zhao, D.; Wang, H.; Liu, M.; Pei, H.; Jin, T.; Yu, D.; et al. Peripheral CD4+ T cell subsets and antibody response in COVID-19 convalescent individuals. J. Clin. Investig. 2020, 130, 6588-6599. [CrossRef]

64. Tangye, S.G.; Ma, C.S.; Brink, R.; Deenick, E.K. The good, the bad and the ugly-T FH cells in human health and disease. Nat. Rev. Immunol. 2013, 13, 412-426. [CrossRef]

65. Kurata, I.; Matsumoto, I.; Sumida, T. T follicular helper cell subsets: A potential key player in autoimmunity. Immunol. Med. 2021, 44, 1-9. [CrossRef] 
66. Collier, J.L.; Weiss, S.A.; Pauken, K.E.; Sen, D.R.; Sharpe, A.H. Not-so-opposite ends of the spectrum: CD8+ T cell dysfunction across chronic infection, cancer and autoimmunity. Nat. Immunol. 2021, 22, 809-819. [CrossRef] [PubMed]

67. Chen, Q.; Yu, B.; Yang, Y.; Huang, J.; Liang, Y.; Zhou, J.; Li, L.; Peng, X.; Cheng, B.; Lin, Y. Immunological and inflammatory profiles during acute and convalescent phases of severe/ critically ill COVID-19 patients. Int. Immunopharmacol. 2021, $97,107685$. [CrossRef]

68. Sudre, C.H.; Murray, B.; Varsavsky, T.; Graham, M.S.; Penfold, R.S.; Bowyer, R.C.; Pujol, J.C.; Klaser, K.; Antonelli, M.; Canas, L.S.; et al. Attributes and predictors of long COVID. Nat. Med. 2021, 27, 626-631. [CrossRef]

69. Malkova, A.; Kudlay, D.; Kudryavtsev, I.; Starshinova, A.; Yablonskiy, P.; Shoenfeld, Y. Immunogenetic predictors of severe COVID-19. Vaccines 2021, 9, 211. [CrossRef]

70. Furman, D.; Hejblum, B.P.; Simon, N.; Jojic, V.; Dekker, C.L.; Thiébaut, R.; Tibshirani, R.J.; Davis, M.M. Systems analysis of sex differences reveals an immunosuppressive role for testosterone in the response to influenza vaccination. Proc. Natl. Acad. Sci. USA 2014, 111, 869-874. [CrossRef] [PubMed]

71. Taneja, V. Sex hormones determine immune response. Front. Immunol. 2018, 9, 1931. [CrossRef]

72. Zhao, Y.; Zhao, Z.; Wang, Y.; Zhou, Y.; Ma, Y.; Zuo, W. Single-Cell RNA Expression Profiling of ACE2, the Receptor of SARS-CoV-2. Am. J. Respir. Crit. Care Med. 2020, 202, 756. [CrossRef] [PubMed]

73. Hou, Y.; Zhao, J.; Martin, W.; Kallianpur, A.; Chung, M.K.; Jehi, L.; Sharifi, N.; Erzurum, S.; Eng, C.; Cheng, F. New insights into genetic susceptibility of COVID-19: An ACE2 and TMPRSS2 polymorphism analysis. BMC Med. 2020, 18, 216. [CrossRef] [PubMed]

74. Cao, Y.; Li, L.; Feng, Z.; Wan, S.; Huang, P.; Sun, X.; Wen, F.; Huang, X.; Ning, G.; Wang, W. Comparative genetic analysis of the novel coronavirus (2019-nCoV/SARS-CoV-2) receptor ACE2 in different populations. Cell Discov. 2020, 6, 11. [CrossRef] [PubMed]

75. Takahashi, T.; Ellingson, M.K.; Wong, P.; Israelow, B.; Lucas, C.; Klein, J.; Silva, J.; Mao, T.; Oh, J.E.; Tokuyama, M.; et al. Sex differences in immune responses that underlie COVID-19 disease outcomes. Nature 2020, 588, 315-320. [CrossRef]

76. The Novel Coronavirus Pneumonia Emergency Response Epidemiology Team. The Epidemiological Characteristics of an Outbreak of 2019 Novel Coronavirus Diseases (COVID-19). China CDC Wkly. 2020, 2, 113-122. [CrossRef]

77. Zeng, F.; Dai, C.; Cai, P.; Wang, J.; Xu, L.; Li, J.; Hu, G.; Wang, Z.; Zheng, F.; Wang, L. A comparison study of SARS-CoV-2 IgG antibody between male and female COVID-19 patients: A possible reason underlying different outcome between sex. J. Med. Virol. 2020, 92, 2050-2054. [CrossRef]

78. Angum, F.; Khan, T.; Kaler, J.; Siddiqui, L.; Hussain, A. The Prevalence of Autoimmune Disorders in Women: A Narrative Review. Cureus 2020, 12, e8094.

79. Wostyn, P. Anosmia as a predictor for post-COVID-19 fatigue syndrome. Lancet Reg. Health-Eur. 2021, 7, 100162. [CrossRef]

80. Shkurnikov, M.; Nersisyan, S.; Jankevic, T.; Galatenko, A.; Gordeev, I.; Vechorko, V.; Tonevitsky, A. Association of HLA Class I Genotypes with Severity of Coronavirus Disease-19. Front. Immunol. 2021, 12, 423. [CrossRef]

81. Langton, D.J.; Bourke, S.C.; Lie, B.A.; Reiff, G.; Natu, S.; Darlay, R.; Burn, J.; Echevarria, C. The influence of HLA genotype on the severity of COVID-19 infection. HLA 2021, 98, 14-22. [CrossRef] [PubMed]

82. Joseph, J.W.; Roberts, J.C.; Weaver, C.N.; Anderson, J.S.; Wong, M.L. Patients with Mild COVID-19 Symptoms and Coincident Pulmonary Embolism: A Case Series. Clin. Pract. Cases Emerg. Med. 2020, 4, 295-298. [CrossRef] [PubMed]

83. Wang, D.; Hu, B.; Hu, C.; Zhu, F.; Liu, X.; Zhang, J.; Wang, B.; Xiang, H.; Cheng, Z.; Xiong, Y.; et al. Clinical Characteristics of 138 Hospitalized Patients with 2019 Novel Coronavirus-Infected Pneumonia in Wuhan, China. JAMA J. Am. Med Assoc. 2020, 323, 1061-1069. [CrossRef] [PubMed]

84. Sartoretti, E.; Sartoretti, T.; Imoberdorf, R.; Dracklé, J.; Sartoretti-Schefer, S. Long-segment arterial cerebral vessel thrombosis after mild COVID-19. BMJ Case Rep. 2020, 13, 236571. [CrossRef] [PubMed] 